\title{
ANIMAL RESEARCH PAPER Effects of different sources of forage in high-concentrate diets on fermentation parameters, ruminal biohydrogenation and microbiota in Nellore feedlot steers
}

\author{
J. D. MESSANA ${ }^{1 *}$, A. L. E. G. F. CARVALHO ${ }^{1}$, A. F. RIBEIRO ${ }^{1}$, G. FIORENTINI ${ }^{1}$, \\ P. S. CASTAGNINO ${ }^{1}$, Y. T. GRANJA-SALCEDO ${ }^{1}$, A. V. PIRES ${ }^{2}$ AND T. T. BERCHIELLI ${ }^{1,3}$ \\ ${ }^{1}$ UNESP - Univ. Estadual Paulista, Faculdade de Ciências Agrárias e Veterinárias, Departamento de Zootecnia, \\ Jaboticabal, São Paulo, Brazil \\ ${ }^{2}$ USP - Universidade de São Paulo, Escola Superior de Agricultura 'Luiz de Queiroz', Departamento de Zootecnia, \\ Piracicaba, São Paulo, Brazil \\ ${ }^{3}$ Membro INCT/CA - UFV - Departamento de Zootecnia, Viçosa, Minas Gerais, Brazil
}

(Received 30 April 2015; revised 4 November 2015; accepted 9 February 2016)

\section{SUMMARY}

Modifying the extent of fatty acid (FA) biohydrogenation $(\mathrm{BH})$ in the rumen through diet formulation is an effective strategy for changing the content of unsaturated FAs (USFAs) in meat. The present study investigated the effects of different sources of forage in high-concentrate diets on intake, digestibility, rumen fermentation, ruminal $\mathrm{BH}$, duodenal flow of FAs and rumen microbiota in Nellore steers. Intake of neutral detergent fibre (NDF) was higher in animals fed with maize silage (MS) than in those fed with sugar cane (SC) and sugar cane bagasse (SB). Higher digestibility of dry matter and NDF was found in animals fed with MS than in those fed with the other diets. In addition, higher crude protein digestibility was observed in animals fed with sugar cane bagasse than in those fed with SC. Non-fibre carbohydrate (NFC) digestibility was higher in animals fed with sugar cane than in those fed with the other diets. Intake of total and individual FAs such as $\mathrm{C} 18: 1$ cis-9, C18:2, and C18:3 was similar between animals fed with MS and SB, but decreased in animals fed with SC. Diets containing MS and SB showed higher total digestibility of saturated FAs (SFAs) and USFAs, respectively and total FAs and ruminal BH of C18:1 and USFA. Intestinal digestibility of overall FAs did not differ among treatments, except for $\mathrm{C} 18: 3$, which increased in animals fed with SC and SB. The profile of FAs in duodenal digesta and faecal outputs did not differ among treatments. However, the flow of NDF was higher in animals fed with SC than in those fed with MS and SB. Animals fed with SB showed higher values of $\mathrm{pH}$ than those fed with MS and SC. Animals fed with SC showed lower values of ammonianitrogen. Protozoan counts were only influenced by diet for species that belonged to the genera Dasytricha and Isotricha. Populations of fibrolytic bacteria (Ruminococus flavefaciens, Ruminococus albus and Fibrobacter succinogenes) were similar among diets. Populations of Selenomonas ruminantium increased 2.5 and 5 times in animals fed with MS when compared with those fed with SC and SB, respectively. The use of MS increased intake and digestibility of NDF, and the use of SC decreased ruminal BH of total USFA without changing the flow of FAs to the duodenum. Thus, different sources of forage in high-concentrate diets do not modify the duodenal flow of USFA or fibrolytic bacteria. This must be taken into account when formulating diets to modulate ruminal upsets without altering intake.

\section{INTRODUCTION}

Consumption of red meat has declined in some European countries because it has an unhealthy composition of saturated fatty acids (SFAs; Van Wezemael

* To whom all correspondence should be addressed. Email: duarte_juliana@hotmail.com et al. 2012). Increasing the levels of linoleic and linolenic fatty acids (FAs) in meat is an effective nutritional strategy to increase product quality (Or-Rashid et al. 2009; Herdmann et al. 2010). Therefore, diet formulation can be used to reduce ruminal FA biohydrogenation $(\mathrm{BH})$ and, consequently, increase unsaturated FAs (USFAs) in meat. 
The proportion of non-fibre carbohydrates (NFCs) in the diet and fibre sources are significant factors that can modify the flow of FAs to the duodenum (Zebeli et al. 2012a). Use of different sources of forage diets with high levels of concentrate may be associated with different ruminal degradation rates and, consequently, lower intake and nutrient digestibility (Tafaj et al. 2005). In vitro studies have shown that the lipolysis rate is altered by diet composition, being more extensive in response to increased nitrogen $(\mathrm{N})$ content in high-starch diets and decreased $\mathrm{N}$ content when dietary fibre is replaced by starch (Shingfield \& Wallace 2014). Conversely, rapid degradation of NFCs (concentrate) leads to high concentrations of volatile FAs and low $\mathrm{pH}$. In spite of this, there is no consensus on $\mathrm{pH}$ thresholds that may cause ruminal upset. One generally accepted indication of ruminal disorders is $\mathrm{pH}<5 \cdot 6-5 \cdot 8$ (Lechartier \& Peyraud 2010), which could create a shift in the microbiome (Hook et al. 2011; Saleem et al. 2012).

Healthy rumen function is maintained by including adequate fibre content in high-concentrate diets that stimulate digesta stratification in the rumen and chewing activity, hence increasing salivary output (Tafaj et al. 2006). Effectiveness of forage in stimulating chewing activity, rumen fermentation and ruminal retention time and, therefore, ruminal microbiota, varies with different botanical origin, processing, particle size (PS) and neutral detergent fibre (NDF) content (Owens et al. 1998). Nevertheless, there is evidence that not all FAs present in forage behave similarly when exposed to bacterial BH (Dewhurst et al. 2006). However, there is a lack of information on the effects of similar NDFs in low-quality forage (fNDFs) in diets with higher concentrate and glycerine on ruminal fermentation, ruminal $\mathrm{BH}$, duodenal flow of FAs and rumen microbiota in Nellore steers. Therefore, it was hypothesized that sources of low-quality forage with different fibre digestibility may be used in high-concentrate diets to modulate ruminal fermentation and FA flow to the duodenum without affecting the intake of Nellore feedlot steers. Thus, the present study aimed to evaluate the effects of different sources of forage in high-concentrate diets on intake, digestibility, rumen fermentation, ruminal $\mathrm{BH}$, duodenal flow of FAs and rumen microbiota in Nellore feedlot steers.

\section{MATERIALS AND METHODS}

The protocol used in the present experiment was in accordance with the Brazilian College of Animal
Experimentation (COBEA - Colégio Brasileiro de Experimentação Animal) guidelines and was approved by the Ethics, Bioethics and Animal Welfare Committee (CEBEA - Comissão de Ética e Bem Estar Animal) of the UNESP - Univ Estadual Paulista, Jaboticabal (protocol number 021118/11).

Animals and experimental feeds

Nine Nellore steers (body weight [BW], $300 \pm 30 \mathrm{~kg}$; age, $18 \pm 2$ months) fitted with 10-cm (internal diameter) silicone-type ruminal cannulas and duodenal Ttype cannulas (Kehl ${ }^{\circledR}$, São Carlos, Brazil) were used in a triple Latin square design $3 \times 3$ to evaluate dietary intake, apparent total tract digestibility, ruminal $\mathrm{pH}$, ammonia- $\mathrm{N}\left(\mathrm{NH}_{3}-\mathrm{N}\right)$ concentration, ruminal $\mathrm{BH}$, duodenal flow of $\mathrm{FAs}$ and rumen microbiota. The steers were fitted with the cannulas at about 10 months of age and underwent at least 8 weeks of recovery before the start of the study. The steers were treated for internal and external parasites at the beginning of the experiment and maintained in individual pens of $\sim 21 \mathrm{~m}^{2}$ for adaptation with protected feeders and water. Initially, the animals were weighed, identified and housed in individual pens with feeders and drinkers. The animals spent 21 days adapting to the facilities and management. The experiment consisted of three consecutive 20-day periods. Each study period consisted of 15 days for adaptation, 4 days for recording dry matter intake (DMI) and faeces collection, and 1 day for ruminal fluid sampling. Ruminal fluid was collected for measuring ruminal $\mathrm{pH}$ and $\mathrm{NH}_{3}-\mathrm{N}$ and quantifying bacteria and protozoa on 1 day during each 20-day period (see later).

The diets were formulated to provide DMI of $22 \mathrm{~g} / \mathrm{kg}$ of BW (6.6 kg per animal/day), calculated using the method described by Alderman (1993) and fNDF was fixed at 0.15 of DMI to ensure ruminal fibre requirements and avoid ruminal upsets (Goulart \& Nussio 2011).

The dietary treatments were as follows: maize silage (MS), sugar cane (SC) and sugar cane bagasse (SB, Table 1). Maize silage used in the present study was obtained from the UNESP farm. A whole plant of the maize hybrid $2 \mathrm{~B} 688 \mathrm{Hx}$ (Dow AgroSciences, Indianapolis, IN, USA) was harvested and ensiled at about $0 \cdot 31 \mathrm{DM}$ and chopped into pieces $5 \mathrm{~cm}$ long. The chopped maize material was placed in a trenchtype silo, covered with black plastic and ensiled for at least 2 months. Sugar cane was obtained from a 
Table 1. Chemical composition of maize silage (MS), sugar cane $(S C)$ and sugar cane bagasse $(S B)(\mathrm{g} / \mathrm{kg}$ on a dry matter basis)

\begin{tabular}{lccc}
\hline \hline & & Forage & \\
\cline { 2 - 4 } Chemical composition & MS & SC & SB \\
\hline DM & 311 & 293 & 630 \\
OM & 946 & 974 & 965 \\
CP & $86 \cdot 8$ & $30 \cdot 3$ & $33 \cdot 2$ \\
NDF & 544 & 555 & 865 \\
iNDF & 170 & 257 & 542 \\
EE & $23 \cdot 8$ & $4 \cdot 20$ & $4 \cdot 00$ \\
Gross energy (MJ/kg) & $17 \cdot 9$ & $17 \cdot 5$ & $17 \cdot 2$ \\
\hline \hline
\end{tabular}

DM, dry matter; OM, organic matter; $C P$, crude protein; NDF, neutral detergent fibre; iNDF, indigestible neutral detergent fibre; $\mathrm{EE}$, ether extract.

local farm and chopped into pieces of about $2-3 \mathrm{~cm}$ in length, while SB was obtained from a private biofuel plant and chopped into pieces $3-4 \mathrm{~cm}$ long. The differences in the length of the forage pieces was due to current practice. Crude glycerine was acquired from the soybean oil-based biodiesel production company ADM, Rondonópolis, Brazil (803.4 g glycerol $/ \mathrm{kg} ; 15.9 \mathrm{~g}$ ether extract $/ \mathrm{kg} ; 50.3 \mathrm{~g}$ ash $/ \mathrm{kg}$ and $120 \cdot 2 \mathrm{~g}$ water $/ \mathrm{kg}$ ).

The diets were isonitrogenous and the concentrate was composed of ground maize, soybean meal, crude glycerine and mineral supplements (Table 2). Ingredients for the concentrate were ground using a hammer mill fitted with strainers and 2-mm sieves. Continuous homogenization of the diets was performed in a horizontal mixer for $15 \mathrm{~min}$.

The animals were fed twice daily at 08.00 and 16.00 and feed refusals were recorded daily for each pen. The concentrates and forage for each animal were weighed individually and mixed manually in the troughs. Throughout the entire experimental period, refusals of $\sim 100 \mathrm{~g} / \mathrm{kg}$ were allowed in relation to the total amount consumed on the previous day. Feed refusals were collected and weighed before feeding; sub-samples of $\sim 100 \mathrm{~g} / \mathrm{kg}$ of feed refusals were collected for each animal and frozen at $-20{ }^{\circ} \mathrm{C}$.

\section{Data collection and sampling procedures}

Total faeces were collected for 4 days between days 15 and 18 (Barbosa et al. 2011). Faeces were collected immediately after each spontaneous defecation and stored in 20-litre buckets. At the end of each 24-h collection period, the buckets were changed and the faeces were weighed, blended manually and aliquots $(\sim 300 \mathrm{~g})$ were collected. Afterwards, these samples were dried in a forced-ventilation oven at $55{ }^{\circ} \mathrm{C}$ for $72 \mathrm{~h}$ and ground in a mill with a 1-mm mesh sieve, and a composite sample was prepared for each animal per period on the basis of the air-dry weight.

Duodenal samples were collected over 2 days (fourth and fifth data collection days during the study period) at 6 -h intervals. The sampling was delayed for $3 \mathrm{~h}$ on the second day to represent the 24- $\mathrm{h}$ period (de Oliveira et al. 2007). The samples were maintained at $-10{ }^{\circ} \mathrm{C}$ and at the end of the period, the samples for each animal were pooled for each period. Indigestible NDF (iNDF) was used as an indicator of daily DM flows in the duodenum (Harvatine \& Allen 2006) and obtained via an in situ method after $240 \mathrm{~h}$ (Casali et al. 2008) with incubated samples of feed offered, feed refusals, faeces and ground duodenal digesta (Wiley mill, 2-mm screen). Indigestible NDF was analysed using an Ankom 200 Fibre Analyser (Ankom Technology Fairport, NY, USA).

Rumen $\mathrm{pH}$ and $\mathrm{NH}_{3}-\mathrm{N}$ were measured on day 18 of each period. To assess rumen fermentation parameters, rumen fluid samples $(c .80 \mathrm{ml})$ were collected manually before supplying the diet (time zero) and 1 , 2, 4, 6, 8, 10 and $12 \mathrm{~h}$ after feeding. Immediately after collection, $\mathrm{pH}$ of the rumen fluid was determined using a digital potentiometer (ORION 710A, Boston, MA, USA). The ruminal fluid $(40 \mathrm{ml})$ was placed in a plastic bottle and frozen at $-20{ }^{\circ} \mathrm{C}$ for $\mathrm{NH}_{3}-\mathrm{N}$ analysis, according to the methodology adapted by Fenner (1965). In brief, ruminal fluid $\mathrm{NH}_{3}$ was analysed by distilling with $2 \mathrm{M}$ potassium hydroxide $(\mathrm{KOH})$ in a micro-Kjeldahl system. 
Table 2. Composition of the experimental diets ( $\mathrm{g} / \mathrm{kg}$ on a dry matter basis)

\begin{tabular}{|c|c|c|c|}
\hline & \multicolumn{3}{|c|}{ Diet } \\
\hline & MS & SC & SB \\
\hline \multicolumn{4}{|l|}{ Ingredient proportion } \\
\hline MS & 288 & & \\
\hline SC & & 275 & \\
\hline SB & & & 173 \\
\hline Maize & 357 & 337 & 451 \\
\hline Soybean meal & 225 & 258 & 246 \\
\hline Crude glycerine & 100 & 100 & 100 \\
\hline Mineral supplement* & $30 \cdot 0$ & $30 \cdot 0$ & $30 \cdot 0$ \\
\hline \multicolumn{4}{|l|}{ Chemical composition } \\
\hline DM & 710 & 737 & 843 \\
\hline OM & 909 & 918 & 920 \\
\hline $\mathrm{CP}$ & 181 & 179 & 179 \\
\hline NDF & 317 & 307 & 333 \\
\hline fNDF & 150 & 150 & 150 \\
\hline $\mathrm{EE}$ & $26 \cdot 4$ & $21 \cdot 2$ & $26 \cdot 0$ \\
\hline $\mathrm{NFC}+$ & 409 & 438 & 410 \\
\hline $\mathrm{ME}(\mathrm{MJ} / \mathrm{kg})$ & $10 \cdot 1$ & $10 \cdot 4$ & $10 \cdot 9$ \\
\hline \multicolumn{4}{|c|}{ Profile of fatty acid (g/100 g FAME) } \\
\hline C14:0 & $0 \cdot 15$ & $0 \cdot 61$ & $0 \cdot 34$ \\
\hline C16:0 & $13 \cdot 8$ & $16 \cdot 4$ & $16 \cdot 2$ \\
\hline $\mathrm{C} 17: 0$ & $0 \cdot 24$ & $0 \cdot 29$ & $0 \cdot 53$ \\
\hline C18:0 & $3 \cdot 31$ & $3 \cdot 45$ & $3 \cdot 74$ \\
\hline C18: 1 cis-9 & $29 \cdot 0$ & $24 \cdot 6$ & $27 \cdot 9$ \\
\hline C18: 2 & $44 \cdot 4$ & $40 \cdot 5$ & $39 \cdot 5$ \\
\hline $\mathrm{C} 18: 3$ & $2 \cdot 62$ & $2 \cdot 14$ & $2 \cdot 16$ \\
\hline SFA & $19 \cdot 5$ & $23 \cdot 1$ & $23 \cdot 4$ \\
\hline USFA & $77 \cdot 5$ & $73 \cdot 3$ & $73 \cdot 0$ \\
\hline MUFA & $30 \cdot 5$ & $26 \cdot 8$ & $30 \cdot 6$ \\
\hline PUFA & $47 \cdot 0$ & $46 \cdot 5$ & $42 \cdot 4$ \\
\hline
\end{tabular}

MS, maize silage; SC, sugar cane; SB, sugar cane bagasse; DM, dry matter; $\mathrm{OM}$, organic matter; $\mathrm{CP}$, crude protein; NDF, neutral detergent fibre; $\mathrm{fNDF}$, NDF from forage; $\mathrm{EE}$, ether extract; $\mathrm{NFC}$, non-fibre carbohydrates; $\mathrm{ME}$, metabolizable energy; FAME, fatty acid methyl esters; SFA, saturated fatty acid; USFA, unsaturated fatty acid; MUFA, monounsaturated fatty acid; PUFA, polyunsaturated fatty acid.

* Composition = 210 g calcium; 20 g phosphorus; 37 g sulphur; 80 g sodium; 490 mg copper; 1.424 mg manganese; 1.830 mg zinc; 36 mg iodine; $29 \mathrm{mg}$ cobalt; 9 mg selenium;333 mg fluorine (max).

+ Non-fibrous carbohydrate (NFC) estimated as: NFC $=100-(C P+E E+$ ash + NDF).

The feed offered, feed refusals and faeces samples were dried at $55{ }^{\circ} \mathrm{C}$ for $72 \mathrm{~h}$ and ground in a Wiley mill (Thomas Scientific, Swedesboro, NJ, USA) to pass through a 1-mm screen. Samples of Tifton 85 hay, concentrates and feed refusals were analysed for DM (934.01), mineral matter (MM, 942.05) and ether extract (EE, 920.39), according to AOAC (1990). Ether extract contents in faeces were determined by extraction in ether (EE, 920.39). Nitrogen was determined using an LECO FP-528 nitrogen analyser (LECO Corp., St. Joseph, MI, USA).
The NDF was determined using $\alpha$-amylase and without the addition of sodium sulphite, according to the method reported by Van Soest et al. (1991) and adapted for the Ankom200 Fibre Analyser (Ankom Technology, Fairport, NY). Acid detergent fibre was determined using the method described by Goering \& Van Soest (1970) and adapted for the Ankom200 Fibre Analyser (Ankom Technology, Fairport, NY). Acid detergent lignin was determined by solubilisation of cellulose with sulphuric acid, according to Van Soest \& Robertson (1985). Gross 
energy was obtained by the combustion of samples in an adiabatic bomb calorimeter IKA ${ }^{\circledR}$ model 2000 Basic.

The flows of DM to the duodenum were calculated as the ratio of iNDF consumed to the concentration of iNDF in duodenal contents. Ruminal $\mathrm{BH}$ was estimated by the differences in USFA between the intakes and flows to the duodenum (Xu et al. 2014).

\section{Fatty acid quantification}

Fatty acid composition was analysed according to the protocol described by Shingfield et al. (2003). Briefly, lipids were extracted from $100 \mathrm{mg}$ of freeze-dried samples in a mixture $(3: 2, \mathrm{v} / \mathrm{v})$ of hexane and isopropanol after adjustment of $\mathrm{pH}$ to 2 by using $2 \mathrm{~m}$ hydrochloric acid and methylation with an acid-based catalyst using methanolic sulphuric acid $(1 \%, \mathrm{v} / \mathrm{v})$. The FA profile was determined using a gas chromatograph (Focus CG - Finnigan, Thermo Finnigan, San Jose, CA, USA) with a fused silica capillary column (100 m $\times 0 \cdot 250 \mathrm{~mm}, 0 \cdot 20-\mathrm{m}$ film thickness; CP-Sil 88 for FA methyl esters - FAME) by using hydrogen as a carrier gas at a constant flow of $1.5 \mathrm{ml} / \mathrm{min}$ ). The flame ionization detector was set at $300{ }^{\circ} \mathrm{C}$. The time-temperature programme used was as follows: initial temperature of $70{ }^{\circ} \mathrm{C}$ for 4 min before increasing to $175^{\circ} \mathrm{C}\left(13^{\circ} \mathrm{C} / \mathrm{min}\right)$ with waiting time of 27 min; $215^{\circ} \mathrm{C}\left(4^{\circ} \mathrm{C} / \mathrm{min}\right)$ with waiting time of $9 \mathrm{~min}$; and finally $230^{\circ} \mathrm{C}\left(7^{\circ} \mathrm{C} / \mathrm{min}\right)$ for $4 \mathrm{~min}$ (total $65 \mathrm{~min}$ ). Identification of FAs was performed by comparing their retention times with those observed in commercial standards (C4-C22) such as Supelco 18919-1AMP, a methyl ester mixture of 37 FAs. The major FAs were identified using the following pure commercial standards: 05632-SIGMA, methyl ester mixture of the conjugated linoleic acid cis-9, trans-11 and trans-10, cis-12; V1381-SIGMA and methyl ester vaccenic acid.

\section{Microbiological analysis}

Samples for bacteria and protozoa quantification were collected on day 19 . For quantification and identification of rumen ciliate protozoa, samples of ruminal contents were collected via cannula, $3 \mathrm{~h}$ after the morning feeding. Cell counts were performed using rumen content aliquots preserved in formalin (a solution of equal parts water and $370 \mathrm{ml} / \mathrm{l}$ formaldehyde), according to D'Agosto \& Carneiro (1999). Ciliate protozoa species were identified and quantified in a Sedgewick-Rafter chamber, according to Dehority
(1984). Each sample was homogenized and $1 \mathrm{ml}$ of ruminal content was pipetted and transferred to vials with Lugol's solution, according to the methodology of D'Agosto \& Carneiro (1999). After $15 \mathrm{~min}, 9 \mathrm{ml}$ of $30 \%$ glycerine was added to the vials. To quantify the protozoa, $1 \mathrm{ml}$ was transferred from each vial to fill the Sedgewick-Rafter chamber.

Bacterial population was quantified using quantitative polymerase chain reaction (qPCR). Samples of ruminal contents were collected via cannula before the morning feeding (Saro et al. 2014). Fifty grams of the rumen contents was weighed and immediately added to $50 \mathrm{ml}$ of phosphate-buffered saline $(\mathrm{pH}$ $7 \cdot 4$ ), stirred vigorously for $3 \mathrm{~min}$, and then filtered with a mesh fabric $(100 \mu \mathrm{m})$. The filtrate was centrifuged at $16000 \mathrm{~g}$ for $10 \mathrm{~min}$ at $4{ }^{\circ} \mathrm{C}$. The supernatant was discarded and the precipitate was resuspended in $4 \mathrm{ml}$ of tris-ethylenediaminetetraacetic acid buffer $(10 \times, \mathrm{pH}$ 8). The re-suspended content was centrifuged at $16000 \mathrm{~g}$ for $10 \mathrm{~min}$ at $4{ }^{\circ} \mathrm{C}$, the supernatant was discarded, and the precipitate stored immediately in a freezer $\left(-20^{\circ} \mathrm{C}\right)$ for 2 months.

A 'Fast spin kit for soil' (MP Bio ${ }^{\circledR}$, Biomedicals, Illkirch, France) extraction kit was used to extract DNA from $250 \mathrm{mg}$ of the sample, according to the manufacturer's instructions. Integrity and quantity of the DNA was checked using agarose gel electrophoresis $(0 \cdot 8 \%)$ and complementary DNA was assessed using a spectrophotometer (Thermo Scientific NanoDrop 1000, Thermo Fisher Scientific, MA).

Absolute quantification of total bacteria and relative quantification of cellulolytic bacteria (Ruminococcus albus, Fibrobacter succinogenes and Ruminococus flavefaciens) was achieved by qPCR. The primers used in the present study are listed in Table 3. Four concentrations $(200,400,600$ and $800 \mathrm{nM})$ of forward and reverse primers were tested to determine minimum primer concentration giving the lowest threshold cycle (Ct) and to reduce non-specific amplification before the start of the reaction. Validation of the chosen concentration of primers was performed with different concentrations of DNA (150, 125, 100, 50 and 25 ng). The value of the 'slope' was determined and efficiency was calculated using the following equation:

$$
\text { Efficiency }=10(-1 / \text { slope })-1
$$

The amplifications were performed in triplicate. Real-time PCR was performed using the Applied Biosystems 7500 Real-time PCR System (Applied Biosystems, Foster City, CA). Rox was used as a 
Table 3. Primers used in the present study

\begin{tabular}{|c|c|c|c|}
\hline Primer & Sequence $\left(5^{\prime}-3^{\prime}\right)$ & $T\left({ }^{\circ} \mathrm{C}\right)^{*}$ & $\begin{array}{l}\text { Efficiency of } \\
\text { primer (\%) }\end{array}$ \\
\hline Fibrobacter succinogenest & $\begin{array}{l}\text { F: GTTCGGAATTACTGGGCGTAAA } \\
\text { R: CGCCTGCCCCTGAACTATC }\end{array}$ & 60 & 98 \\
\hline Ruminococcus flavefacienst & $\begin{array}{l}\text { F:CGAACGGAGATAATTTGAGTTTACTTAGG } \\
\text { R: CGGTCTCTGTATGTTATGAGGTATTACC }\end{array}$ & 62 & 96 \\
\hline Ruminococcus albust & $\begin{array}{l}\text { F: CCCTAAAAGCAGTCTTAGTTCG } \\
\text { R:CCTCCTTGCGGTTAGAACA }\end{array}$ & 55 & 97 \\
\hline Selenomonas ruminantium $\ddagger$ & $\begin{array}{l}\text { F: GGCGGGAAGGCAAGTCAGTC } \\
\text { R: CСТCTCCTGCACTCAAGAAAGACAG }\end{array}$ & 60 & 98 \\
\hline Total Archaeas§ & $\begin{array}{l}\text { F: TTC GGT GGA TCD CAR AGR GC } \\
\text { R: GBA RGT CGW AWC CGT AGA ATCC }\end{array}$ & 60 & 98 \\
\hline
\end{tabular}

F, forward; R, reverse.

* Temperature of annealing.

† Denman \& McSweeney (2006).

₹ Khafipour et al. (2009).

$\S$ Denman et al. (2007).

passive reference dye. The qPCR was performed using $100 \mathrm{ng}$ of total DNA in a reaction containing $6 \cdot 25 \mu \mathrm{l}$ of SYBR $^{\circledR}$ Green PCR Master Mix (Bio-Rad, Hercules, CA), 400 or $600 \mathrm{nM}$ of the primer pair and water to a final volume of $12.5 \mu \mathrm{l}$. Cycling conditions were $50{ }^{\circ} \mathrm{C}$ for $2 \mathrm{~min}$ and $95^{\circ} \mathrm{C}$ for $10 \mathrm{~min}$, followed by 35 cycles of denaturation at $95^{\circ} \mathrm{C}$ for $15 \mathrm{~s}$, pairing at $60{ }^{\circ} \mathrm{C}$ for $60 \mathrm{~s}$ and extension at $78{ }^{\circ} \mathrm{C}$ for $1 \mathrm{~min}$. After one cycle of amplification, a step was added to increase the temperature from 60 to $95^{\circ} \mathrm{C}$ to obtain the dissociation curve of the reaction products for analysing amplification specificity.

Relative quantification was used to determine species proportion. The results were expressed as a $16 \mathrm{~S}$ rDNA ratio of general bacteria:

$$
\text { Relative quantification }=2^{-(\mathrm{Ct} \text { target-Ct total bacteria })}
$$

where $\mathrm{Ct}$ is defined as the number of cycles required for the fluorescent signal to cross the threshold.

\section{Statistical analyses}

The data of intake, digestibility, ruminal $\mathrm{BH}$, duodenal FA flows and protozoa populations were analysed using a triple $3 \times 3$ Latin square design with the PROC MIXED procedure of SAS (version 9.2). The general mathematical model was as follows:

$$
Y_{i j k}=\mu+\alpha_{i}+\beta_{j}+s_{k}+\alpha \beta_{i j}+e_{i j k}
$$

where $Y_{i j k}$ represents the observation of steers $k$ given diet $i$ at period $j ; \mu$ represents overall mean; $\alpha_{i}$ represents the fixed effect of the ith diet, $i=1,2, \ldots$, $n t ; \beta_{j}$ represents the fixed effect of the $j$ th period, $j=$ $1,2, \ldots, n p ;$ and $s_{k}$ represents the random effect of the $k$ th steers, $k=1,2, \ldots, n s, \mu ; \alpha \beta_{i j}$ represents the interaction between diet $i$ and period $j$; and $e_{i j k}$ represents the residual experimental error with variance component $\sigma 2 c$ (Tempelman 2004).

Ruminal $\mathrm{pH}$ and $\mathrm{NH}_{3}-\mathrm{N}$ data were analysed using a triple $3 \times 3$ Latin square design with repeated measures over time and the PROC MIXED procedure of SAS (version 9.2). The model included fixed effects of diet, time, diet $\times$ time interaction and random effects of steers and periods. The structure of errors that best fitted the data according to the Bayesian information criterion was used. Differences between treatment means were determined using Tukey's test. Differences among means with $P<0.05$ were accepted as representing statistically significant differences.

Relative quantities of $16 \mathrm{~S}$ rRNA, as determined using real-time PCR, were analysed using $\mathrm{R}$ software (version 3.1.1), with three treatments and three periods. The fixed effects were treatments and Latin Square, and random effects were time, animal and error. When significant, the means between treatments were compared using Tukey's test and the significance was set at $P<0 \cdot 05$.

\section{RESULTS}

There was no effect of different sources of forage in high-concentrate diets on DM, organic matter (OM) 
Table 4. Effect of different sources of forage in diets with crude glycerine on intake and digestibility of dry matter $(D M)$, organic matte $(O M)$, crude protein $(C P)$, ether extract $(E E)$, neutral detergent fibre $(N D F)$ and non-fibre carbohydrates (NFC) by feedlot Nellore steers

\begin{tabular}{|c|c|c|c|c|c|}
\hline \multirow[b]{2}{*}{ Parameters } & \multicolumn{3}{|c|}{ Diet } & \multirow[b]{2}{*}{ S.E.M. } & \multirow[b]{2}{*}{$P$-value } \\
\hline & MS & SC & SB & & \\
\hline \multicolumn{6}{|c|}{ Intake $(\mathrm{kg} / \mathrm{d})$} \\
\hline DM & $7 \cdot 1$ & $6 \cdot 3$ & $6 \cdot 4$ & $0 \cdot 56$ & 0.501 \\
\hline OM & $7 \cdot 0$ & $5 \cdot 9$ & $6 \cdot 1$ & $0 \cdot 47$ & $0 \cdot 231$ \\
\hline $\mathrm{CP}$ & $1 \cdot 3$ & $1 \cdot 1$ & $1 \cdot 4$ & $0 \cdot 11$ & $0 \cdot 187$ \\
\hline $\mathrm{EE}$ & $0 \cdot 18$ & $0 \cdot 13$ & $0 \cdot 19$ & 0.019 & 0.030 \\
\hline NDF & $2 \cdot 4$ & $1 \cdot 7$ & $1 \cdot 7$ & $0 \cdot 19$ & $0 \cdot 035$ \\
\hline NFC* & $3 \cdot 1$ & $3 \cdot 2$ & $2 \cdot 2$ & $0 \cdot 28$ & $<0 \cdot 001$ \\
\hline \multicolumn{6}{|c|}{ Total digestibility $(\mathrm{g} / \mathrm{kg})$} \\
\hline DM & 808 & 759 & 750 & $12 \cdot 3$ & $0 \cdot 006$ \\
\hline OM & 826 & 773 & 787 & $19 \cdot 6$ & $0 \cdot 134$ \\
\hline $\mathrm{CP}$ & 772 & 737 & 796 & $17 \cdot 0$ & $0 \cdot 020$ \\
\hline $\mathrm{EE}$ & 862 & 828 & 862 & $16 \cdot 2$ & 0.066 \\
\hline NDF & 708 & 454 & 468 & $27 \cdot 7$ & $<0 \cdot 001$ \\
\hline NFC* & 914 & 947 & 906 & $11 \cdot 2$ & $<0 \cdot 001$ \\
\hline
\end{tabular}

MS, maize silage; SC, sugar cane; SB, sugar cane bagasse; DM, dry matter; $\mathrm{OM}$, organic matter; $\mathrm{CP}$, crude protein; $\mathrm{EE}$, ether extract; NDF, neutral detergent fibre; NFC, non-fibre carbohydrate.

* Non-fibre carbohydrates $=100-(\mathrm{CP}+\mathrm{EE}+\mathrm{ash}+\mathrm{NDF}), \mathrm{NRC}(2001)$.

and CP intake. However, NDF intake was higher in animals fed with MS than in animals fed with SC, which did not differ from animals fed with SB. The NFC intake $(P<0 \cdot 05)$ was reduced in animals fed with SB compared with those fed MS and SC. A higher intake of EE was observed in animals fed with SB and MS than in animals fed with SC (Table 4).

Digestibility of DM and NDF increased $(P<0.05)$ when the MS diet was used. In addition, higher crude protein $(\mathrm{CP})$ digestibility was observed in animals fed with $\mathrm{SB}$ and MS than in those fed with SC $(P<0 \cdot 05)$. The NFC digestibility was higher in animals fed with SC than in those fed with the other diets $(P<0 \cdot 05$, Table 4$)$.

Intakes $(\mathrm{g} / \mathrm{d})$ of total and individual $\mathrm{FAs}$, such as C18:1 cis-9, C18:2 and C18:3, were similar between animals fed with MS and $\mathrm{SB}$, but decreased in animals fed with SC $(P<0 \cdot 05$, Table 5). Diets containing MS and SB showed higher values for total digestibility of SFA, USFA and total FAs $(P<$ 0.05). Ruminal $\mathrm{BH}$ of $\mathrm{C} 18: 1$ and USFA was higher in animals fed with $\mathrm{SB}$ and MS than in animals fed with SC $(P<0 \cdot 05$, Table 5). Overall, intestinal digestibility of FAs (g/100 g) did not differ among treatments, except for C18:3, which increased in animals fed with SC and SB $(P<0 \cdot 05$, Table 5).

The profile of FAs in duodenal digesta and faecal outputs did not differ among treatments. However, the flow of NDF was higher in animals fed with SC than in those fed with MS and SB $(P<0 \cdot 05$, Table 6).

There was no interaction between diet and time for $\mathrm{pH}$ or $\mathrm{NH}_{3}-\mathrm{N}$. Animals fed with SB showed higher values of $\mathrm{pH}(P<0.05)$ than those fed with MS and SC. Animals fed with SC showed decreased $\mathrm{NH}_{3}-\mathrm{N}$ values $(P<0 \cdot 05$, Table 7$)$.

The protozoan populations were not influenced by the different sources of forage in high-concentrate diets, with the exception of Dasytricha and Isotricha (Table 8). Dasytricha populations were higher in animals fed with SC than those fed with SB and MS. In addition, Isotricha populations were higher $(P<$ $0 \cdot 05)$ in animals fed with SC. The populations of fibrolytic bacteria ( $R$. flavefaciens, $R$. albus and $F$. succinogenes) were similar among diets (Table 8). However, the population of Selenomonas ruminantium, a bacterium that consumes lactic acid, increased 2.5 and 5 times $(P<0.01)$ in animals fed with MS when compared with animals fed with $\mathrm{SC}$ and $\mathrm{SB}$, respectively. Moreover, the populations of methanogens were similar among diets. 
Table 5. Effect of different sources of forage in diets with crude glycerine on intake, total and intestinal digestibility of fatty acid, ruminal biohydrogenation of unsaturated fatty acids by feedlot Nellore steers

\begin{tabular}{|c|c|c|c|c|c|}
\hline & \multicolumn{3}{|c|}{ Diet } & \multirow[b]{2}{*}{ S.E.M. } & \multirow[b]{2}{*}{$P$-value } \\
\hline & MS & SC & SB & & \\
\hline \multicolumn{6}{|c|}{ Intakes of $F A(g / d)$} \\
\hline C18:0 & $6 \cdot 1$ & $4 \cdot 7$ & $6 \cdot 5$ & $0 \cdot 72$ & $0 \cdot 060$ \\
\hline C18: 1 cis-9 & 52 & 36 & 55 & $6 \cdot 0$ & $0 \cdot 013$ \\
\hline $\mathrm{C} 18: 2$ & 81 & 59 & 90 & $9 \cdot 1$ & $0 \cdot 016$ \\
\hline $\mathrm{C} 18: 3$ & $4 \cdot 3$ & $3 \cdot 7$ & $5 \cdot 3$ & $0 \cdot 50$ & $0 \cdot 046$ \\
\hline SFA & 73 & 26 & 35 & $3 \cdot 9$ & $0 \cdot 062$ \\
\hline USFA & 137 & 99 & 151 & 16 & $0 \cdot 015$ \\
\hline Total FA* & 171 & 125 & 186 & 19 & $0 \cdot 019$ \\
\hline \multicolumn{6}{|c|}{ Digestible component $(\mathrm{g} / \mathrm{kg})$} \\
\hline SFA & 616 & 389 & 506 & 68 & $0 \cdot 0003$ \\
\hline USFA & 956 & 942 & 954 & $6 \cdot 5$ & $0 \cdot 012$ \\
\hline Total FA* & 891 & 829 & 872 & 17 & $0 \cdot 0001$ \\
\hline \multicolumn{6}{|c|}{ Biohydrogenation $(\mathrm{g} / \mathrm{kg})$} \\
\hline $\mathrm{C} 18: 1$ & 605 & 416 & 575 & 47 & $0 \cdot 021$ \\
\hline $\mathrm{C} 18: 2$ & 694 & 709 & 799 & 57 & $0 \cdot 063$ \\
\hline $\mathrm{C} 18: 3$ & 708 & 751 & 810 & 52 & $0 \cdot 220$ \\
\hline USFA & 622 & 523 & 671 & 50 & $0 \cdot 046$ \\
\hline \multicolumn{6}{|c|}{ Intestinal digestibility $(\mathrm{g} / \mathrm{kg})$} \\
\hline C18:0 & 702 & 688 & 618 & 53 & $0 \cdot 238$ \\
\hline $\mathrm{C} 18: 1$ & 897 & 894 & 871 & 20 & $0 \cdot 321$ \\
\hline $\mathrm{C} 18: 2$ & 904 & 928 & 909 & 18 & $0 \cdot 365$ \\
\hline $\mathrm{C} 18: 3$ & 793 & 902 & 903 & 40 & $0 \cdot 020$ \\
\hline SFA & 716 & 664 & 659 & 47 & $0 \cdot 413$ \\
\hline USFA & 876 & 874 & 851 & 26 & $0 \cdot 443$ \\
\hline Total FA* & 802 & 768 & 752 & 39 & $0 \cdot 304$ \\
\hline
\end{tabular}

MS, maize silage; SC, sugar cane; SB, sugar cane bagasse; SFA, saturated fatty acid; USFA, unsaturated fatty acid; Total FA, total fatty acid.

* Total FA = sum of $\mathrm{C} 10: 0, \mathrm{C} 12: 0, \mathrm{C} 14: 0, \mathrm{C} 16: 0, \mathrm{C} 17: 0, \mathrm{C} 18: 0, \mathrm{C} 16: 1, \mathrm{C} 18: 1$ cis-9, C18: 2 and $\mathrm{C} 18: 3$.

\section{DISCUSSION}

According to Piatkowski et al. (1990) and Hoffmann (1990), addition of at least $400 \mathrm{~g}$ of structural crude fibre per $100 \mathrm{~kg}$ of animal BW to a concentrate-rich diet is necessary to ensure sufficient amounts of fibre for adequate ruminal fermentation. Thus, in the present study, fNDF was fixed at a proportion of $0 \cdot 15$ of the diet to avoid ruminal upsets. This level of fNDF inclusion was recommended by Goulart \& Nussio (2011), who suggested that ruminal functions may not be affected at this inclusion level in concentrate-rich diets. Thus, in the present study, forage: concentrate was different among the diets $(\mathrm{MS}=288 \mathrm{~g} / \mathrm{kg}$, $\mathrm{SC}=275 \mathrm{~g} / \mathrm{kg}$ and $\mathrm{SB}=173 \mathrm{~g} / \mathrm{kg}$ ), because of the different NDF contents from the forage sources studied $(\mathrm{MS}=544 \mathrm{~g} / \mathrm{kg}, \mathrm{SC}=555 \mathrm{~g} / \mathrm{kg}$ and $\mathrm{SB}=865 \mathrm{~g} / \mathrm{kg})$.
The reduction in NDF intake in animals fed with low-quality forages could be due to lower fibre digestion of these sources (Corrêa et al. 2003; Rotta et al. 2014), which results in NDF accumulation and limitation of voluntary intake (Ørskov \& Hovell 1978). However, in diets with high proportions of concentrate, the intake is rarely limited by physical fill (Galyean \& Defoor 2003). Thus, the results for NDF intake were possibly due to the animals sorting through their feed and tending to sort mixed rations to a greater extent in diets with low forage content (DeVries et al. 2007, 2008). The NDF content of refusals was $0.53,0.83$ and $1.25 \mathrm{~kg} \mathrm{NDF/day} \mathrm{for} \mathrm{MS,} \mathrm{SC}$ and SB diets, respectively, This suggests that animals fed with MS actively sought those parts of the diet with high NDF content in an attempt to increase the 
Table 6. Effect of different sources of forage in diets with crude glycerine on duodenal flow of dry matter (DM), neutral detergent fibre (NDF) and fatty acid and faecal outputs in feedlot Nellore steers

\begin{tabular}{|c|c|c|c|c|c|}
\hline & \multicolumn{3}{|c|}{ Diet } & \multirow[b]{2}{*}{ S.E.M. } & \multirow[b]{2}{*}{$P$-value } \\
\hline & MS & SC & SB & & \\
\hline \multicolumn{6}{|c|}{ Duodenal flows $(\mathrm{kg} / \mathrm{d})$} \\
\hline DM & $2 \cdot 61$ & 3.08 & $2 \cdot 78$ & $0 \cdot 358$ & $0 \cdot 652$ \\
\hline NDF & $0 \cdot 62$ & $1 \cdot 02$ & $0 \cdot 89$ & $0 \cdot 098$ & $0 \cdot 034$ \\
\hline \multicolumn{6}{|c|}{ Fatty acids $(\mathrm{g} / \mathrm{d})$} \\
\hline C18:0 & $10 \cdot 3$ & $12 \cdot 1$ & $12 \cdot 2$ & $1 \cdot 64$ & $0 \cdot 670$ \\
\hline C18: 1 cis-9 & $24 \cdot 7$ & $22 \cdot 7$ & $23 \cdot 1$ & $4 \cdot 12$ & $0 \cdot 913$ \\
\hline C18: 2 & $22 \cdot 9$ & $17 \cdot 9$ & $19 \cdot 5$ & 3.96 & $0 \cdot 445$ \\
\hline C18: 3 & $1 \cdot 35$ & 0.90 & $1 \cdot 03$ & $0 \cdot 226$ & $0 \cdot 142$ \\
\hline SFA & $41 \cdot 8$ & $43 \cdot 6$ & $45 \cdot 2$ & $6 \cdot 305$ & $0 \cdot 918$ \\
\hline USFA & $54 \cdot 3$ & $46 \cdot 5$ & $48 \cdot 9$ & $9 \cdot 20$ & $0 \cdot 730$ \\
\hline Total FA* & $96 \cdot 1$ & $90 \cdot 1$ & $94 \cdot 0$ & $15 \cdot 3$ & 0.943 \\
\hline \multicolumn{6}{|c|}{ Faecal outputs $(\mathrm{kg} / \mathrm{d})$} \\
\hline DM & $1 \cdot 40$ & $1 \cdot 50$ & $1 \cdot 57$ & $0 \cdot 143$ & $0 \cdot 702$ \\
\hline NDF & 0.69 & $0 \cdot 92$ & $0 \cdot 95$ & $0 \cdot 083$ & $0 \cdot 080$ \\
\hline Total FA* & $17 \cdot 2$ & $20 \cdot 2$ & $20 \cdot 1$ & $1 \cdot 874$ & 0.443 \\
\hline
\end{tabular}

MS, maize silage; SC, sugar cane; SB, sugar cane bagasse; SFA, saturated fatty acid; USFA, unsaturated fatty acid; Total FA, total fatty acids.

$*$ Total FA = sum of $\mathrm{C} 10: 0, \mathrm{C} 12: 0, \mathrm{C} 14: 0, \mathrm{C} 16: 0, \mathrm{C} 17: 0, \mathrm{C} 18: 0, \mathrm{C} 16: 1, \mathrm{C} 18: 1$ cis-9, C18:2 and C18:3.

intake of physically effective fibre and reduce the intake of starch, indicating that cattle may adapt their feed selection to minimize ruminal disturbances (DeVries et al. 2014).

The results highlight the concept of physically effective NDF (peNDF) used by Zebeli et al. (2012b) as a more accurate indicator of fibre adequacy when compared with fNDF: it combines information on chemical fibre content and PS of feedstuffs. Nutritional effects of dietary PS and peNDF are complex and involve feed intake behaviour (absolute intake and sorting behaviour), ruminal mat formation, rumination and salivation and ruminal motility.

The different sources of forage in the high-concentrate diets changed DM and NDF digestibility, which could be related to the passage rate and fibre quality. Sugar cane and SB have low digestibility and high concentrations of iNDF. Since high-concentrate diets may increase the passage rate, fibre degradation could be limited and lead to reduced NDF digestibility (Galyean \& Defoor 2003). This is consistent with observations by Henrique et al. (2007) and Menezes et al. (2011), who reported that SB and SC have low digestibility and high concentrations of iNDF. Diets containing fibre with higher fractions of iNDF associated with a high concentrate in the diet may have a higher passage rate (Pereira et al. 2000; Mertens 2001; Magalhães 2006), preventing further degradation of the fibre and resulting in lower digestibility of NDF, as observed in animals fed with SB and SC.

Treatment with $\mathrm{SB}$ and MS showed the highest intake of FA C10:0, C12:0, C18:1 cis-9, linoleic (C18:2), linolenic (C18:3), UFA and total FAs. This is probably due to FA composition of individual ingredients and chemical composition of the experimental diets.

Among the three forage sources, the highest concentrations of $\mathrm{C} 10: 0, \mathrm{C} 12: 0, \mathrm{C} 16: 0, \mathrm{C} 17: 0, \mathrm{C} 18$ : 0 and C16:1 were found in SB. Maize silage had the highest concentrations of $\mathrm{C} 18: 1$ cis-9, C18:2, C18:3 and UFA. Substantial concentrations of all FAs analysed were found in soybean meal and ground maize.

Fixing the proportion of NDF in the diets at 0.15 led to the MS treatment having the highest proportion of forage $(288 \mathrm{~g} / \mathrm{kg}$ DM) while the SB treatment had the lowest $(173 \mathrm{~g} / \mathrm{kg} \mathrm{DM})$. Therefore, the MS treatment presented the lowest inclusion of maize $(357 \mathrm{~g} / \mathrm{kg}$ DM) and soybean meal (225 g/ $\mathrm{kg}$ DM) and the SB treatment, the highest (451 g maize/kg DM and $246 \mathrm{~g}$ soybean meal/kg DM). Therefore, different quantities 
Table 7. Effect of different sources of forage in diets with crude glycerine on $\mathrm{pH}$ and ammonia nitrogen $\left(\mathrm{NH}_{3}-\mathrm{N}\right)$

\begin{tabular}{|c|c|c|c|c|c|c|c|}
\hline \multirow[b]{2}{*}{ Parameters } & \multicolumn{3}{|c|}{ Diet } & \multirow[b]{2}{*}{ S.E.M. } & \multicolumn{3}{|c|}{$P$-value } \\
\hline & MS & SC & SB & & D & $\mathrm{T}$ & $\mathrm{D} \times \mathrm{T}$ \\
\hline $\mathrm{pH}$ & $6 \cdot 08$ & $6 \cdot 27$ & $6 \cdot 40$ & 0.085 & $<0 \cdot 001$ & $<0 \cdot 001$ & 0.617 \\
\hline $\mathrm{NH}_{3}-\mathrm{N}(\mathrm{mg} / \mathrm{dl})$ & $15 \cdot 4$ & $11 \cdot 5$ & $15 \cdot 4$ & $1 \cdot 23$ & $<0.001$ & $<0 \cdot 001$ & 0.586 \\
\hline
\end{tabular}

MS, maize silage; SC, sugar cane; SB, sugar cane bagasse; $\mathrm{D}$, diet; $\mathrm{T}$, time effect; $\mathrm{D} \times \mathrm{T}$, diet and time interaction effect.

Table 8. Effect of different sources of forage in diets with crude glycerine on rumen fluid protozoa numbers, relative proportion of cellulolytic bacteria and methanogenic archaeas of Nellore steers in feedlot

\begin{tabular}{|c|c|c|c|c|c|}
\hline & \multicolumn{3}{|c|}{ Diet } & \multirow[b]{2}{*}{ S.E.M. } & \multirow[b]{2}{*}{$P$-value } \\
\hline & MS & SC & SB & & \\
\hline \multicolumn{6}{|l|}{ Protozoa $\left(n \times 10^{5} / \mathrm{ml}\right)$} \\
\hline Entodinium & $6 \cdot 18$ & $6 \cdot 04$ & $6 \cdot 05$ & $0 \cdot 09$ & $0 \cdot 140$ \\
\hline Dasytricha & $4 \cdot 08$ & $4 \cdot 48$ & $3 \cdot 63$ & $0 \cdot 23$ & $0 \cdot 026$ \\
\hline Isotricha & $3 \cdot 88$ & $4 \cdot 56$ & $3 \cdot 66$ & $0 \cdot 14$ & $<0 \cdot 005$ \\
\hline Diploplastron & $3 \cdot 88$ & $4 \cdot 40$ & $3 \cdot 88$ & $0 \cdot 23$ & 0.437 \\
\hline Polyplastron & $4 \cdot 15$ & $4 \cdot 08$ & $3 \cdot 87$ & $0 \cdot 24$ & $0 \cdot 224$ \\
\hline Protozoa total & $17 \cdot 76$ & $19 \cdot 08$ & $17 \cdot 54$ & $1 \cdot 53$ & 0.637 \\
\hline \multicolumn{6}{|l|}{ Bacteria } \\
\hline Ruminoccocus albus & 0.007 & $0 \cdot 002$ & $0 \cdot 001$ & 0.001 & $0 \cdot 205$ \\
\hline Ruminoccocus flavefaciens & 0.003 & $0 \cdot 007$ & $0 \cdot 001$ & $0 \cdot 001$ & $0 \cdot 524$ \\
\hline Fibrobacter succinogenes & $0 \cdot 570$ & $0 \cdot 440$ & $0 \cdot 450$ & $0 \cdot 042$ & $0 \cdot 363$ \\
\hline Selenomonas ruminantium & 0.005 & $0 \cdot 002$ & $0 \cdot 001$ & $0 \cdot 001$ & $<0 \cdot 001$ \\
\hline Archeas total & $0 \cdot 054$ & $0 \cdot 067$ & $0 \cdot 052$ & 0.003 & 0.076 \\
\hline
\end{tabular}

MS, maize silage; SC, sugar cane; SB, sugar cane bagasse.

of the concentrate in the diets modified the ingestion of $\mathrm{EE}$ and consequently, the quantity of FAs.

Digestibility of SFA, total FA and BH of UFA were higher for the SB and MS treatments than for the SC treatment. Reduction in UFA BH in the SC treatment could be explained by the fast passage rate, which resulted in inadequate attachment of lipids to fibre particles because of the reduced superficial area for bacterial adhesion and BH (Dewhurst et al. 2003). This is in agreement with the higher duodenal flow of NDF in the SC and SB treatments. The physical and chemical characteristics of forage, such as density and fibre concentration (e.g., NDF), are associated with modifications in the kinetics of ruminal fermentation and FA flow (Defoor et al. 2002).

Biohydrogenation of $\mathrm{C} 18: 1$ in animals fed with SB and MS was higher than that in animals fed with SC. According to Murphy et al. (1987), BH of C18: 1 cis-
9 increased by $38-73 \%$ in concentrate-rich diets. The intermediate $\mathrm{C} 18: 1$ is preferably hydrogenated to C18:0 because of its high availability in the ruminal environment (Loor et al. 2002).

The low ruminal $\mathrm{pH}$ in concentrate-rich diets can limit ruminal $\mathrm{BH}$, with reduction of conjugated linoleic acid and trans C18: 1 formation (Kalscheur et al. 1997), which suggests inhibition of isomerases (Van Nevel \& Demeyer 1996; Troegeler-Meynadier et al. 2006). However, Loor et al. (2004) also demonstrated that changes in the extent of $\mathrm{BH}$ can be independent of ruminal $\mathrm{pH}$ in diets with high proportions of concentrates. Biohydrogenation of C18:1, C18:2, C18:3 and UFA was lower (about 10-20\%) when compared with experimental diets containing reduced proportions of the concentrate. Biohydrogenation can be modified by starch (Zened et al. 2011) and inhibited in diets rich in NFCs (Kucuk et al. 2001; Loor et al. 2004). 
In contrast to NDF flow, duodenal flow of FAs did not differ among the treatments. There was a considerable difference between the results of the present study and those obtained by Murphy et al. (1987), Loor et al. (2002) and Shingfield et al. (2011). This can be explained mainly by animal production specificity (milk or meat) and diet type. There was no interaction among sources of forage with respect to the digestibility of C18:0, C18:1, C18:2, SFA, UFA and total FAs, as demonstrated by the similar duodenal flow of FAs among the diets.

Although the diets were formulated with the same concentration of $\mathrm{fNDF}$, the ruminal $\mathrm{pH}$ was affected by forage source. The increased $\mathrm{pH}$ in $\mathrm{SC}$ and $\mathrm{SB}$ diets could be explained by the positive effect of fibre on ruminal motility and salivary production (Tafaj et al. 2005). The greater fermentability of MS was due to NDF digestibility $(>0.7$ in the present study; Taylor \& Allen 2005) and possibly lower peNDF (Zebeli et al. 2012b), whereas other forage sources such as SB (digestibility, 0.46) affect ruminal buffer capacity and consequently reduce the $\mathrm{pH}$. In addition, because of the high fermentability of MS NDF, animals fed this diet sought fibrous particles high in NDF within the ration to reduce discomfort associated with low ruminal $\mathrm{pH}$ conditions, suggesting that cattle will attempt to select a diet to normalize rumen conditions (DeVries et al. 2008). The present study demonstrated this effect because animals fed with $\mathrm{SB}$ were more efficient at maintaining adequate $\mathrm{pH}$; however, $8 \mathrm{~h}$ after feeding, the ruminal $\mathrm{pH}$ of animals fed with MS had reduced to 6 . In addition, the minimum ruminal $\mathrm{pH}$ value in the present study was $5 \cdot 88$, which does not characterize sub-acute ruminal acidosis. This result could be attributed to the inclusion of crude glycerine in the diets and forage PS. According to Shin et al. (2012), glycerine is more rapidly fermented in the rumen than starch, which may not lower ruminal $\mathrm{pH}$. Furthermore, according to DeVries et al. (2014), diets with higher proportions of concentrate and forage PS $<1.9 \mathrm{~cm}$ tend to attenuate the effects of acidosis in cattle.

Carbohydrate availability determines the rate of microbial growth in the rumen and efficiency of ruminal $\mathrm{NH}_{3}-\mathrm{N}$ utilization. Increasing amounts of readily fermentable carbohydrates such as sugar decrease $\mathrm{NH}_{3}-\mathrm{N}$ concentrations because of improved $\mathrm{N}$ uptake by ruminal microbes (Bach et al. 2005). In addition, Chamberlain et al. (1985) reported that sucrose was more effective than starch in reducing ruminal ammonia concentration, which is in accordance with the present results.

Diet is a major factor that influences rumen microbial composition because of the substrate preferences of microbes and, indirectly, by modifying the rumen environment because of fermentation of the ingested substrates. The genus Entodinium is most resistant to low ruminal $\mathrm{pH}$, representing $0.90-0.99$ of the total protozoa population in cattle fed high grain diets (Hristov et al. 2001). In addition, Holotrichid protozoa (Isotricha and Dasytricha) use soluble sugars for metabolism, and cattle fed with SC tend to have a greater population of these protozoa (Ryle \& Ørskov 1987).

Increased NFC intake has been associated with acidic rumen conditions that reduce the activities of fibrolytic bacteria and increase the activities of amylolytic and lactic-acid-utilizing bacteria in the rumen (Nagaraja \& Titgemeyer 2007). In the present study, three ruminal bacteria important for fibre degradation were found; they are highly sensitive to low $\mathrm{pH}$ when values remain $<6 \cdot 0$, which results in reduced activity (Russell \& Dombrowski 1980). In the present study, $\mathrm{pH}$ in all diets remained above 6.0 and this was the main factor responsible for the fact that the quantified cellulolytic species were not affected. The results are consistent with the observations reported by a previous study that showed that $F$. succinogenes and other cellulolytic species such as $R$. albus and $R$. flavefaciens did not disappear completely from diets with high proportions of concentrate (Petri et al. 2012).

According to Nagaraja \& Titgemeyer (2007), S. ruminantium can tolerate low $\mathrm{pH}$ and has the ability to utilize starch and sugars for growth; thus, higher numbers of $S$. ruminantium in MS diets could be because the forage source added starch to the diet and led to lower ruminal $\mathrm{pH}$ in animals fed this diet. Furthermore, the different sources of forage in diets with crude glycerine did not influence total Archaeas population, which is agreement with methane emission measurements.

In summary, the present study suggests that the inclusion of low-quality forages to provide similar fNDF in diets with crude glycerine does not affect intake, digestibility of $\mathrm{OM}$, fibrolytic bacteria, and total number of microbes that belong to Archaeas. Use of MS increased intake and digestibility of NDF, and use of SC decreased ruminal $\mathrm{BH}$ of total USFA without changing the flow of FAs to the duodenum. The different source of forage at $0 \cdot 15$ of fNDF can be used in diet formulation to modulate ruminal 
disturbances without altering feed intake or the FA profile.

The authors would like to thank the São Paulo Research Foundation (FAPESP) for providing financial support through grant \# 2011/00060-8, \# 2013/ 06379-1, \# 2013/04625-5, and \# 2014/09033-1.

\section{REFERENCES}

Alderman, G. (1993). Energy and Protein Requirements of Ruminants: an Advisory Manual prepared by the AFRC Technical Committee on Responses to Nutrients. Wallingford, UK: CAB International.

AOAC (Association of Official Analytical Chemistry) (1990). Official Methods of Analysis, 15th edn. Arlington, VA: AOAC International.

Bach, A., Calsamiglia, S. \& Stern, M. D. (2005). Nitrogen metabolism in the rumen. Journal of Dairy Science $\mathbf{8 8}$ (Suppl.), E9-E21.

Barbosa, A. M., Valadares, R. F. D., Valadares Filho, S. C., Pina, D.S., DetmanN, E. \& Leão, M.l. (2011). Endogenous fraction and urinary recovery of purine derivatives obtained by different methods in Nellore cattle. Journal of Animal Science 89, 510-519.

Casali, A. O., Detmann, E., Valadares Filho, S. C., Pereira, J. C., Henriques, L. T., De Freitas, S. G. \& Paulino, M. F. (2008). Influence of incubation time and particles size on indigestible compounds contents in cattle feeds and feces obtained by in situ procedures. Revista Brasileira de Zootecnia 37, 335-342.

Chamberlain, D. G., Thomas, P. C., Wilson, W., Newbold, C. J. \& MACDOnALD, J.C. (1985). The effects of carbohydrate supplements on ruminal concentrations of ammonia in animals given diets of grass silage. Journal of Agricultural Science, Cambridge 104, 331-340.

Corrêa, C. E. S., Pereira, M. N., de Oliveira, S. G. \& Ramos, M. H. (2003). Performance of Holstein cows fed sugarcane or corn silages of different grain textures. Scientia Agricola 60, 621-629.

D'Agosto, M.T. \& Carneiro, M. E. (1999). Evaluation of lugol solution used for counting rumen ciliates. Revista Brasileira de Zoologia 16, 725-729.

Defoor, P. J., Galyean, M. L., Salyer, G. B., Nunnery, G. A. \& PARSONS, C. H. (2002). Effects of roughage source and concentration on intake and performance by finishing heifers. Journal of Animal Science 80, 1395-1404.

Dehority, B. A. (1984). Evaluation of subsampling and fixation procedures used for counting rumen protozoa. Applied and Environmental Microbiology 48, 182-185.

Denman, S. E. \& McSweeney, C. S. (2006). Development of a real-time PCR assay for monitoring anaerobic fungal and cellulolytic bacterial populations within the rumen. FEMS Microbiology Ecology 58, 572-582.

Denman, S. E., Tomkins, N. W. \& Mcsweeney, C. S. (2007). Quantitation and diversity analysis of ruminal methanogenic populations in response to the antimethanogenic compound bromochloromethane. FEMS Microbiology Ecology 62, 313-322.

de Oliveira, S. G., Berchielli, T. T., Pedreira, M. S., Primavesi, O., Frighetto, R. \& Lima, M. A. (2007). Effect of tannin levels in sorghum silage and concentrate supplementation on apparent digestibility and methane emission in beef cattle. Animal Feed Science and Technology 135, 236-248.

Devries, T. J., Beauchemin, K. A. \& Von Keyserlingk, M. A. G. (2007). Dietary forage concentration affects the feed sorting behavior of lactating dairy cows. Journal of Dairy Science 90, 5572-5579.

Devries, T. J., Dohme, F. \& Beauchemin, K. A. (2008). Repeated ruminal acidosis challenges in lactating dairy cows at high and low risk for developing acidosis: feed sorting. Journal of Dairy Science 91, 3958-3967.

Devries, T. J., Schwaiger, T., Beauchemin, K. A. \& Penner, G. B. (2014). Impact of severity of ruminal acidosis on feedsorting behaviour of beef cattle. Animal Production Science 54, 1238-1242.

Dewhurst, R. J., Evans, R. T., Scollan, N. D., Moorby, J. M., MerRY, R. J. \& WiLKINS, R. J. (2003). Comparisons of grass and legume silages for milk production. 2. In vivo and in sacco evaluations of rumen function. Journal of Dairy Science 86, 2612-2621.

Dewhurst, R. J., Shingfield, K. J., Lee, M. R. F. \& Scollan, N. D. (2006) Increasing the concentrations of beneficial polyunsaturated fatty acids in milk produced by dairy cows in high-forage systems. Animal Feed Science and Technology 131, 168-206.

FENNER, H. (1965). Method for determining total volatile bases in rumen fluid by steam distillation. Journal of Dairy Science 48, 249-251.

Galyean, M. L. \& Defoor, P. J. (2003). Effects of roughage source and level on intake by feedlot cattle. Journal of Animal Science 81 (E Suppl. 2), E8-E16.

Goering, H. K. \& Van Soest, P.J. (1970). Forage Fiber Analyses (Apparatus, Reagents, Procedures, and Some Applications). Agriculture Handbook 379. Washington, DC: USDA-ARS.

Goulart, R. S. \& Nussio, L. G. (2011). Exigência de fibra fisicamente efetiva para bovinos confinados. In Proc. VII Simpósio de pecuária de corte e II, pp. 111-154. Lavras, Brazil: NEPEC.

Harvatine, K. J. \& Allen, M. S. (2006). Effects of fatty acid supplements on ruminal and total tract nutrient digestion in lactating dairy cows. Journal of Dairy Science 89, 10921103.

Henrique, W., Beltrame Filho, J. A., Leme, P. R., Lanna, D. P. D., Alleoni, G. F., Coutinho Filho, J. L. V. \& Sampaio, A. A. M. (2007). Avaliação da silagem de grãos de milho úmido com diferentes volumosos para tourinhos em terminação: Desempenho e características de carcaça. Revista Brasileira de Zootecnia 36, 183-190.

Herdmann, A., Martin, J., Nuernberg, G., Dannenberger, D. \& NuernBerG, K. (2010). Effect of dietary n-3 and n-6 PUFA on lipid composition of different tissues of German holstein bulls and the fate of bioactive fatty acids during processing. Journal of Agricultural and Food Chemistry 58, 8314-8321. 
HoffmanN, M. (1990). Tierfütterung. Berlin: Deutscher Landwirtschaftsverlag.

Hook, S. E., Steele, M.A., Northwood, K.S., Dijkstra, J., France, J., Wright, A. D. G. \& McBride, B. W. (2011). Impact of subacute ruminal acidosis (SARA) adaptation and recovery on the density and diversity of bacteria in the rumen of dairy cows. FEMS Microbiology Ecology 78, 275-284.

Hristov, A. N., Ivan, M., Rode, L. M. \& McAllister, T.A. (2001). Fermentation characteristics and ruminal ciliate protozoal populations in cattle fed medium- or high-concentrate barley-based diets. Journal of Animal Science 79, 515-524.

Kalscheur, K. F., Teter, B. B., Piperova, L. S. \& Erdman, R. A. (1997). Effect of dietary forage concentration and buffer addition on duodenal flow of trans-C18:1 fatty acids and milk fat production in dairy cows. Journal of Dairy Science 80, 2104-2114.

Khafipour, E., Li, S., Plaizier, J. C. \& Krause, D. O. (2009). Rumen microbiome composition determined using two nutritional models of subacute ruminal acidosis. Applied and Environmental Microbiology 75, 7115-7124.

Kucuk, O., Hess, B. W., Ludden, P. A. \& Rule, D. C. (2001). Effect of forage:concentrate ratio on ruminal digestion and duodenal flow of fatty acids in ewes. Journal of Animal Science 79, 2233-2240.

Lechartier, C. \& Peyraud, J. L. (2010). The effects of forage proportion and rapidly degradable dry matter from concentrate on ruminal digestion in dairy cows fed corn silage-based diets with fixed neutral detergent fiber and starch contents. Journal of Dairy Science 93, 666-681.

Loor, J. J., Herbein, J. H. \& Jenkins, T. C. (2002). Nutrient digestion, biohydrogenation, and fatty acid profiles in blood plasma and milk fat from lactating Holstein cows fed canola oil or canolamide. Animal Feed Science and Technology 97, 65-82.

Loor, J. J., Ueda, K., Ferlay, A., Chilliard, Y. \& Doreau, M. (2004). Biohydrogenation, duodenal flow, and intestinal digestion of trans fatty acids and conjugated linoleic acids in response to dietary forage: concentrate ratio and linseed oil in dairy cows. Journal of Dairy Science 87, 2472-2485.

Magalhães, A. L. R., Campos, J. M. S., Cabral, L. S., Mello, R., de Freitas, J. A., Torres, R. A., Valadares Filho, S. C. \& de Assıs, A. J. (2006). Cana-de-açúcar em substituição à silagem de milho em dietas para vacas em lactação: parâmetros digestivos e ruminais. Revista Brasileira de Zootecnia 35, 591-599.

Menezes, G. C. C., Valadares Filho, S. C., Magalhães, F. A., Valadares, R. F. D., Mariz, L. D., Detmann, E., Pereira, O. G. \& LEÃO, M. I. (2011). Total and partial digestibility, rates of digestion obtained with rumen evacuation and microbial protein synthesis in bovines fed fresh or ensiled sugar cane and corn silage. Revista Brasileira de Zootecnia 40, 1104-1113.

Mertens, D. R. (2001). Physical effective NDF and its use in formulating dairy rations. In Simpósio Internacional em Bovinos de Leite. 2. Lavras, Anais. pp. 25-36. Lavras, Brazil: UFLA-FAEPE.
Murphy, M., Udén, P., Palmquist, D. L. \& Wiktorsson, H. (1987). Rumen and total diet digestibilities in lactating cows fed diets containing full-fat rapeseed. Journal of Dairy Science 70, 1572-1582.

Nagaraja, T. G. \& Titgemeyer, E. C. (2007). Ruminal acidosis in beef cattle: the current microbiological and nutritional outlook. Journal of Dairy Science $\mathbf{9 0}$ (Suppl. 1), E17-E38.

National Research Council (2001). Nutrient Requirements of Dairy Cattle, 7. rev. edn. Washington, DC: National Academy Press.

Or-Rashid, M. M., Wright, T. C. \& McBride, B. W. (2009). Microbial fatty acid conversion within the rumen and the subsequent utilization of these fatty acids to improve the healthfulness of ruminant food products. Applied Microbiology and Biotechnology 84, 1033-1043.

ØrSKOV, E. R. \& HOVELL, F.D.D. (1978). Rumen digestion of hay (measured with dacron bags) by cattle given sugar cane or pangola hay. Tropical Animal Production 3, 9-11.

Owens, F. N., Secrist, D. S., Hill, W. J. \& Gill, D. R. (1998). Acidosis in cattle: a review. Journal of Animal Science 76, 275-286.

Pereira, E. S., Queiroz, A. C., Paulino, M. F., Cecon, P. R., Valadares Filho, S. C., Miranda, L. F., Fernandes, A. M. \& CABRAL, L. S. (2000). Determinação das frações protéicas e de carboidratos e taxas de degradação in vitro da cana-de-açúcar, da cama de frango e do farelo de algodão. Revista Brasileira de Zootecnia 29, 1887-1893.

Petri, R. M., Forster, R. J., Yang, W., McKinnon, J.J. \& MCAllister, T. A . (2012). Characterization of rumen bacterial diversity and fermentation parameters in concentrate fed cattle with and without forage. Journal of Applied Microbiology 112, 1152-1162.

Piatkowskı, B., Gürtler, H. \& Voigt, J. (1990). Grundzüge der Wiederkäuer-Ernährung. Jena: Gustav Fischer Verlag.

Rotta, P. P., Valadares Filho, S. C., Engle, T. E., Silva, L. C., Sathler, D. F. T., Prado, I. N., Bonafé, E. G., Zawadzki, F. \& Visentainer, J. V. (2014). The impact of dietary sugar cane addition to finishing diets on performance, apparent digestibility, and fatty acid composition of Holstein $\times$ Zebu bulls. Journal of Animal Science 92, 2641-2653.

RusselL, J. B. \& Dombrowski, D. B. (1980). Effect of pH on the efficiency of growth by pure cultures of rumen bacteria in continuous culture. Applied and Environmental Microbiology 39, 604-610.

RYLE, M. \& ØrSKOV, E. R. (1987). Rumen ciliates and tropical feeds. World Animal Review 64, 21-30.

Saleem, F., Ametaj, B. N., Bouatra, S., Mandal, R., Zebeli, Q., DUNN, S. M. \& WISHART, D. S. (2012). A metabolomics approach to uncover the effects of grain diets on rumen health in dairy cows. Journal of Dairy Science 95, 66066623.

Saro, C., Ranilla, M. J., Cifuentes, R., Rosselló-Mora, R. \& CARro, M. D. (2014). Technical note: comparison of automated ribosomal intergenic spacer analysis and denaturing gradient gel electrophoresis to assess bacterial diversity in the rumen of sheep. Journal of Animal Science 92, 1083-1088.

Shin, J. H., Wang, D., Kim, S. C., Adesogan, A. T. \& Staples, C. R. (2012). Effects of feeding crude glycerine on 
performance and ruminal kinetics of lactating Holstein cows fed corn silage-or cottonseed hull-based, low-fiber diets. Journal of Dairy Science 95, 4006-4016.

Shingfield, K. J. \& Wallace, R. J. (2014). Synthesis of conjugated linoleic acid in ruminants and humans. In Conjugated Linoleic Acids and Conjugated Vegetable Oils (Eds B. Sels \& A. Philippaerts), pp. 1-65. RSC Catalysis Series no. 9. Cambridge, UK: Royal Society of Chemistry.

Shingfield, K. J., Ahvenjarvi, S., Toivonen, V., Arola, A., Nurmela, K. V. V., Huhtanen, P. \& Grinari, J. M. (2003). Effect of dietary fish oil on biohydrogenation of fatty acids and milk fatty acid content in cows. Animal Science 77, 165-179.

Shingfield, K. J., Lee, M. R. F., Humphries, D. J., Scollan, N. D., Tolvonen, V., Beever, D. E. \& Reynolds, C. K. (2011). Effect of linseed oil and fish oil alone or as an equal mixture on ruminal fatty acid metabolism in growing steers fed maize silage-based diets. Journal of Animal Science 89, 37283741.

Tafaj, M., Kolanecl, V., Junck, B., Maulbetsch, A., Steingass, H. \& Drochner, W. (2005). Influence of fiber content and concentrate level on chewing activity, ruminal digestion, digesta passage rate and nutrient digestibility in dairy cows in late lactation. AsianAustralasian Journal of Animal Sciences 18, 1116-1124.

Tafaj, M., Zebelı, Q., Maulbetsch, A., Steingass, H. \& Drochner, W. (2006). Effects of fibre concentration of diets consisting of hay and slowly degradable concentrate on ruminal fermentation and digesta particle size in midlactation dairy cows. Archives of Animal Nutrition 60, 254-266.

TAYlor, C. C. \& Allen, M. S. (2005). Corn grain endosperm type and brown midrib 3 corn silage: site of digestion and ruminal digestion kinetics in lactating cows. Journal of Dairy Science 88, 1413-1424.

Tempelman, R. J. (2004). Experimental design and statistical methods for classical and bioequivalence hypothesis testing with an application to dairy nutrition studies. Journal of Animal Science 82(e Suppl.), E162-E172.
Troegeler-Meynadier, A., Bret-Bennis, L. \& Enjalbert, F. (2006). Rates and efficiencies of reactions of ruminal biohydrogenation of linoleic acid according to $\mathrm{pH}$ and polyunsaturated fatty acids concentrations. Reproduction Nutrition Development 46, 713-724.

Van Nevel, C. \& Demeyer, D. (1996). Influence of pH on lipolysis and biohydrogenation of soybean oil by rumen contents in vitro. Reproduction Nutrition Development 36, 53-63.

Van Soest, P. J. \& Robertson, J. B. (1985). Analysis of Forages and Fibrous Foods. Ithaca, NY: Cornell University Press.

Van Soest, P. J., Robertson, J. B. \& Lewis, B. A. (1991). Methods for dietary fiber, and nonstarch polysaccharides in relations to animal nutrition. Journal of Dairy Science 74, 3583-3597.

Van Wezemael, L., Ueland, O., Rødbotten, R., de Smet, S., Scholderer, J. \& VerbeKe, W. (2012). The effect of technology information on consumer expectations and liking of beef. Meat Science 90, 444-450.

Xu, L., Jin, Y., He, M. L., Li, C., Beauchemin, K. A. \& Yang, W. Z. (2014). Effects of increasing levels of corn dried distillers grains with solubles and monensin on ruminal biohydrogenation and duodenal flows of fatty acids in beef heifers fed high-grain diets. Journal of Animal Science 92, 1089-1098.

Zebelı, Q., Metzler-Zebeli, B. U. \& Ametaj, B. N. (2012a). Meta-analysis reveals threshold level of rapidly fermentable dietary concentrate that triggers systemic inflammation in cattle. Journal of Dairy Science 95, 2662-2672.

Zebelı, Q., Aschenbach, J. R., TafaJ, M., Boguhn, J., AmetaJ, B. N. \& Drochner, W. (2012b). Invited review: role of physically effective fiber and estimation of dietary fiber adequacy in high-producing dairy cattle. Journal of Dairy Science 95, 1041-1056.

Zened, A., Troegeler-Meynadier, A., Nicot, M. C., Combes, S., Cauquil, L., Farizon, Y. \& Enjalbert, F. (2011). Starch and oil in the donor cow diet and starch in substrate differently affect the in vitro ruminal biohydrogenation of linoleic and linolenic acids. Journal of Dairy Science 94, 56345645 . 